\title{
A Casa das Fazendas Pretas, o comércio e o luto na segunda metade do século XIX'
}

Casa das Fazendas Pretas, urban trade, and mourning practices in the late 19th century

hitps://doi.org/10.1590/1982-02672021v29e50

\author{
JULIANA SCHMITT² \\ https: / / orcid.org/0000-000 1-5770-0436 \\ Universidade Federal de Juiz de Fora / Juiz de Fora, MG, Brasil
}

RESUMO: A Casa das Fazendas Pretas foi um estabelecimento comercial localizado no Rio de Janeiro, entre a segunda metade do século XIX e a primeira do século XX. Anunciando em sua publicidade ser a "única no seu gênero", era especializada em tecidos e artigos para o luto e o meio-luto. Ao reconstituir sua história, é possível observar o desenvolvimento deste tipo de comércio próprio do Oitocentos em meio à modernização do centro da capital carioca, a preocupação com a etiqueta lutuosa e o lugar social que essas regras ocupavam na vida da elite e das classes médias naquele período. Com esse objetivo, as fontes primárias usadas para este estudo foram revistas femininas e de variedades, acessadas através da Hemeroteca Digital da Biblioteca Nacional, e documentos sob guarda do Arquivo Nacional, no Rio de Janeiro.

PALAVRAS-CHAVE: Casa das Fazendas Pretas. Luto. História do vestuário. Rio de Janeiro. Século XIX.

ABSTRACT: The Casa das Fazendas Pretas (House of Funerary trousseaus) was a commercial establishment located in Rio de Janeiro between the second half of the 19th century and the first half of the 20th century. Aimed at being "the only one of its kind," as stated in its advertising, it was specialized in fabrics and articles for mourning and half-mourning. In

\begin{abstract}
1. Este artigo é parte da pesquisa de pós-doutorado intitulada $O$ vestuário de luto no Brasil oitocentista, realizada no Programa de Pós-Graduação em Artes, Cultura e Linguagens da Universidade Federal de Juiz de Fora, sob supervisão da professora doutora Maria Claudia Bonadio.

2. Historiadora formada pela Universidade Estadual de Londrina, onde também se especializou em história e teorias da arte. É mestra em moda, cultura e arte pelo Centro Universitário Senac e doutora em letras pela Universidade de São Paulo. Realizou pesquisa de pós-doutorado em artes, cultura e linguagens pela Universidade Federal de Juiz de Fora e, atualmente, dedica-se ao mestrado em história na Universidade Federal de São Paulo. É professora e pesquisadora nas áreas de história da arte, da literatura, do vestuário e da moda. E-mail:<juschmittju@gmail. com>.
\end{abstract}


retracing its history, one may observe the development of this particular kind of commerce, the concern with the mourning etiquette, and the social place occupied by these rules in the life of the elite and the middle classes at that time. This study was conducted with women's and general interest magazines accessed through the National Library website and documents found in the National Archives, in Rio de Janeiro.

KEYWORDS: Casa das Fazendas Pretas. Mourning. Fashion history. Rio de Janeiro. 19th century. 
O luto foi tema caro à moda do século XIX. $\bigcirc$ período viu desenvolver-se uma etiqueta lutuosa das mais complicadas, que se manifestava, com maior veemência, no vestuário. As regras para o traje de luto, que incluíam as cores, os tecidos e os acessórios adequados, eram rígidas e pormenorizadas, o que exigia, àqueles que as seguissem, disciplina, parcimônia e investimentos. Por isso, não é estranho que todo um comércio relacionado ao luto tenha florescido no Oitocentos, especialmente a partir de meados do século, voltado principalmente ao consumo das elites e das classes médias.

Esse foi um fenômeno observado em todo o Ocidente, mas com particular expressão nos centros urbanos da Europa, Estados Unidos e América Latina. Funerárias, floristas, marmorarias, artigos de papelaria em geral - uma gama imensa de serviços e produtos passaram a fazer parte do complexo cerimonial da morte no período vitoriano. E o vestuário de luto, por ser um de seus aspectos mais visíveis e observados, tornou-se um nicho de mercado valioso a ser explorado. A historiadora inglesa Lou Taylor afirma, em seu Mourning Dress (1983), que comerciantes e industriais com interesses nesse ramo podiam fazer bons negócios - e alguns construíram verdadeiras fortunas. ${ }^{3}$ Muitas dessas lojas se fixavam em pontos nevrálgicos das cidades, em grandes avenidas ou ruas consideradas elegantes. Por exemplo, em Paris, a Grand Maison de Noir, no Faubourg St Honoré, próxima ao ateliê de Charles Worth (nome fundamental da moda no Oitocentos, considerado o iniciador da Alta-Costura) e À L'Immortelle, na Rue de Rivoli, ou ainda as várias maisons de devil da Regent Street, em Londres. As grandes lojas de departamento, fenômeno característico da segunda metade do século XIX que invade as cidades do mundo ocidental, também aproveitavam a mourning mania ${ }^{4}$ daquele momento para abrir suas próprias seções dedicadas ao luto, beneficiando-se de seus já existentes estoques de materiais e aviamentos e oficinas de costura.

No Brasil, era principalmente no Rio de Janeiro, capital do Império e depois da República, que os estabelecimentos comerciais dedicados à produção e venda de objetos para o luto se instalavam. Dentre eles, destaca-se a Casa das Fazendas Pretas, primeira loja especializada em tecidos e artigos indumentários de luto e meio-luto de que se tem registro no Brasil. Sua história é ainda pouco conhecida e foi buscada em documentos sob guarda do Arquivo Nacional, visitado em 25 de outubro de 2019, e em notas, anúncios e matérias
4. A expressão, que pode ser traduzida como "luto mania", é usada por Taylor para denominar a obsessão pelas formas materiais do luto, própria da segunda metade do século XIX. No vestuário, pode ser observada em sua ampla adoção por todas as camadas sociais, pelo aumento exagerado de sua duração e por sua extensão para graus de parentesco cada vez mais remotos (TAYLOR, 1983a). O tema também foi analisado por Schmitt (2010). 
5. Todas as citações de jornais e revistas feitas neste artigo são de edições reproduzidas e acessadas no site da Hemeroteca da Biblioteca Nacional: <https://bit. ly/3z4tGS5>.

6. Coleção Junta Comercial, código 46, livro 645 , registro $10.868,1871$.

7. Não foi possível determinar o exato parentesco entre os dois homens. Há de se registrar que ambos, no contrato de sociedade encontrado no Arquivo Nacional, assinam o primeiro sobrenome como "Sequeira". A confusão da forma escrita desse sobrenome permanece em diversos documentos - ora sendo grafado $\operatorname{com} i$, ora $\operatorname{com} e$. Pode-se observar a última forma no recibo de compras de Maria Amália Ferreira Lage, mencionado na nota 15 , pertencente à Coleção Soares Sampaio, do Arquivo Histórico do Museu Mariano Procópio, em Juiz de Fora (MG). Neste artigo foi adotada a forma "Siqueira", cuja ocorrência nas fontes da época é mais frequente.

8. Conforme relata John Luccock em sua passagem pelo Rio de Janeiro, em 1808, sobre as lojas de dois andares na Rua da Quitanda, dedicadas ao varejo (apud ITALIANO et al., 2015, p. 49).

9. O Paiz, 18 ago. 1906 , p. 2.

10. Jornal do Commercio, 18 ago. 1871. Manteve-se a grafia original.

11. Os períodos de luto, independentemente do grau de parentesco com o morto, geralmente eram divididos em luto fechado e meio-luto ou luto aliviado. A primeira etapa era de grande sobriedade e permitia apenas o uso da cor preta. A segunda, mais permissiva, possibilitava o uso de outras cores junto do preto, como o branco, tons de roxo e publicadas na imprensa fluminense da época, acessíveis por meio da Hemeroteca Digital da Biblioteca Nacional. ${ }^{5}$

\section{CASA DAS FAZENDAS PRETAS: "ÚNICA NO SEU GÊNERO"}

Conforme contrato localizado no Arquivo Nacional, ${ }^{6}$ em 15 de agosto de 1871 os portugueses Pedro de Siqueira Queiroz e Domingos de Siqueira Queiroz 7 se associavam para abrir um estabelecimento comercial dedicado à venda de fazendas de luto e meio-luto. Domingos, sócio em comandita, teria investido um capital bastante superior ao de Pedro: dez contos de réis, contra dois deste último. Oacordo foi oficializado no Tribunal do Commercio da Corte.

Ainda segundo o documento, Pedro de Siqueira Queiroz residia no centro da cidade, à Rua da Quitanda, número 15, e montou a loja no andar de cimaum arranjo comum à época. ${ }^{8}$ Pedro já tinha experiência como caixeiro de outros estabelecimentos, ${ }^{9}$ mas foi a sociedade com Domingos que possibilitou a ele abrir a própria loja que, num primeiro momento, venderia exclusivamente artigos de luto. A inauguração ocorreu em 18 de agosto daquele ano e repercutiu na imprensa local, como confirma a nota "Avisos", publicada no Jornal do Commercio:

- FAZENDAS PARA LUTO. - Os Srs. Pedro de Siqueira Queiroz \& C. acabão de abrir á rua da Quitanda n. 15, sobrado, uma casa especial de fazendas pretas para luto pesado, assim como de fazendas pretas e brancas, próprias para luto aliviado, e especialidade para trajos de viúvas. Encontrão-se na mesma casa gorgorões, paletós de seda, renda, chapéos e muitos outros objectos de adorno. Este novo estabelecimento merece ser visitado. ${ }^{10}$

A nota revela informações interessantes. Além dos tecidos em preto para o luto pesado, a loja disponibilizava fazendas brancas para o meio-luto, acompanhando todas as etapas desse processo. " Destacava os trajes de viúva como sua especialidade, o que provavelmente chamava positivamente a atenção da clientela, tendo em vista a complexidade desse tipo de toilette, mantido por períodos longos. ${ }^{12}$ Oferecia gorgorões, material muito usado nessas ocasiões, e outras peças destinadas a completar um guarda-roupa de enlutado.

Cinco meses depois, o Correio do Brazil, em 18 de janeiro de 1872, publica na seção "Especiais" o seguinte aviso: 
Convidando as famílias a visitarem o seu estabelecimento, á rua da Quitanda n. 15, sobrado, os Srs. Pedro de Siqueira Queiroz \& C. previniram-se, alem dos artigos e fazendas de lucto e meio lucto, que formam a sua especialidade, de outros artigos e fazendas da moda, da mais completa elegância como sejam: chapéos de filó preto para senhora, bem como de velludo, grenadinas brancas e pretas, de todas as qualidades e bonitos padrões, sortimento de vidrilhos, espantoso em qualidades, gostos e feitios, paletos de gorgorão, sedas pretas de todas as qualidades, sedas riscadas, lãs de variados gostos, rendas, camizinhas, leques, sombrinhas, e tudo isto em branco e preto.

Ha na mesma casa todas as fazendas que a moda tem apropriado ás senhoras viuvas.

Como especimen do negocio em que se fez especialista o estabelecimento, encontra-se o mais aprimorado sortimento em linda exposição nas duas grandes vidraças que guarnecem o corredor da casa. Vale a pena visitar o estabelecimento. ${ }^{13}$

Pela comparação entre as duas notas reproduzidas acima, a oferta de produtos parece ter aumentado de maneira considerável em pouco tempo, tanto em quantidade quanto em variedade, dispondo a loja de "outros artigos e fazendas da moda, da mais completa elegância". Sabemos, por edições do Jornal do Commercio e de $\bigcirc$ Globo, que Pedro de Siqueira Queiroz, já no ano de 1872, recebia com frequência encomendas trazidas por paquetes provenientes da França e da Inglaterra. ${ }^{14}$ Gradualmente, a Casa das Fazendas Pretas parece ter se firmado como uma referência no comércio de mercadorias de luto, tendo clientes da aristocracia mesmo fora da capital fluminense. ${ }^{15}$

De acordo com nossas pesquisas, durante a década de 1870, o estabelecimento contou com anúncios publicitários principalmente em dois veículos: - Jornal do Commercio e a Gazeta de Noticias. O primeiro registro é de 14 de fevereiro de 1876, quando um chamativo box de texto no centro de uma página apresentou a "Casa Especial de Fazendas Pretas" com a significativa alcunha de "única no seu gênero", que seria usada em muitos outros reclames nos anos posteriores. Nesse mesmo anúncio, constatamos a mudança de endereço da loja, do número 15 para o número 13 da rua da Quitanda. Por volta de 1882, 0 número 17 do logradouro também foi adquirido. ${ }^{16}$

A mudança representa uma considerável ampliação de serviços: no novo local, mais espaçoso, começava a funcionar uma oficina de costura comandada por uma contramestra francesa ${ }^{17}$ para preparar com maior rapidez e qualidade as encomendas de luto sob medida. A loja contaria ainda com caixeiros viajantes, entrega em domicílio e uma novíssima seção de "roupas de cores", isto é, peças que não eram especificamente para luto. Havia ali exposição permanente de trajes, provavelmente em bonecos tipo manequins e em móveis envidraçados. cinza e azul escuro, ou mesmo estampados delicados nesses tons.

12. O luto da viúva era o que deveria ser mantido por mais tempo e variava, de acordo com as normativas da época, de um ano (segundo a legislação portuguesa) a dois anos e meio (como apregoava a etiqueta inglesa). Muitas viúvas adotavam o meio-luto pelo resto da vida, seguindo o modelo da rainha Vitória da Inglaterra. Cf. Taylor (1983a) e Schmitt, op. cit.

13. Correio do Brazil, 18 jan. 1872, p. 2. Manteve-se a grafia original.

14. No Jornal do Commercio, a informação aparece em 2 de setembro de 1874 ; 20 de novembro de 1875; 3 de outubro de 1877; 15 de maio de 1878; 4 de junho de 1878; 27 de maio de 1879; e 29 de abril de 1881. Por sua vez, no jornal $O$ Globo, consta em 17 de setembro de 1874; 24 de fevereiro de 1875; 25 de março de 1875; 3 de abril de 1875 ; 4 de julho de 1875; e 28 de agosto de 1875 .

15. É o que indica o recibo de compras presente na coleção de objetos pessoais de Maria Amália Ferreira Lage (1834-1914), esposa do barão e comendador Mariano Procópio Ferreira Lage (1821-1872), ambos residentes de Juiz de Fora, Minas Gerais. O casal pertencia à elite mineira $\mathrm{e}$ mantinha relações próximas com a família imperial. Dona Maria Amália tornou-se viúva em 14 de fevereiro de 1872 e, logo após, em 24 de março, comprou um corte de dez côvados de cassa na cor preta na Casa das Fazendas Pretas. O documento faz parte da Coleção Soares Sampaio, do Arquivo Histórico do Museu Mariano Procópio, em Juiz de Fora, e foi consultado em 30 de outubro de 2019. 
16. Esse processo de crescimento da loja é contado em uma longa nota comemorativa dos 35 anos da Casa das Fazendas Pretas, publicada no jornal $\mathrm{O} P a i z$, em 18 de agosto de 1906 (p. 2): "Foi modestíssima a [primeira] instalação, mas a excellencia da sua Idea ficou logo assignalada pela grande affluencia de freguezes, que diariamente subiam ao $1^{\circ}$ andar daquele prédio e pela necessidade que logo se lhe impoz de tomar a loja n. 15 da mesma rua, para ampliar o negocio, que já lhe ia exigindo outras instalações. Ahi, nessa nova casa, foi tal o desenvolvimento do negocio, que o Sr. Siqueira Queiroz poude pensar em organizar uma outra secção de seu estabelecimento - o rayon de cores, o que ainda mais contribuiu para lhe augmentar a freguezia, tornando-se-lhe necessário adquirir o prédio contiguo, n. 17, para fazer uma só casa, mais vasta e com maiores commodidades para a sua cada vez mais crescente clientela". Manteve-se a grafia original.

17. Cf., por exemplo, anúncio na Gazeta de Noticias de 22 de setembro de 1884 , p. 2, entre outros.

18. O fim da sociedade foi registrado no Tribunal do Commercio em 1874. Cf. Coleção Junta Comercial, livro 43, registro 15.285, 1875 .

19. Não foi possível precisar a data - provavelmente entre 18 e 23 de dezembro, conforme noticiou o jornal o Apostolo: Periodico religioso, moral e doutrinário, consagrado aos interesses da religião e da sociedade, do Rio de Janeiro, em 17 de janeiro de 1877 , e a $G a$ zeta de Noticias, de 18 de janeiro de 1877 , em sua primeira página.

20. Não foi possível confirmar a ordem dos nascimen-
Naqueles anos, a sociedade entre Pedro e Domingos termina de maneira amigável ${ }^{18}$ e Pedro se torna proprietário único da loja. Enquanto tratava de expandir os negócios, casou-se com Adelina Soares Ribeiro em dezembro de 1877, ${ }^{19}$ com quem teve seus filhos Pedro, Octavio e Adelina, além de Rosina e Manuel, falecidos ainda na infância. ${ }^{20}$ Nas décadas seguintes, Queiroz parece ter viajado diversas vezes para a Europa, sozinho ou com a família, e muitas dessas idas foram notificadas pela imprensa. Em algumas dessas ausências, chegava a fixar moradia temporária. Fazia questão de divulgar essas viagens na publicidade da Casa das Fazendas Pretas, como mostra o anúncio no Jornal do Commercio, publicado em 1 de outubro de 1891, que informava a chegada de "completo e variado sortimento de vestidos, capas de sedas e lãs, chapéos, rendas, guarnições e tecidos de sedas, lãs e lãs e sedas, etc, etc., tudo quanto há de mais novo e de bom gosto, escolhido pelo chefe da casa actualmente em Pariz" - as duas últimas palavras em destaque, escritas em caixa alta. ${ }^{21}$

A atenção dada pela imprensa fluminense a essas viagens pode indicar seu reconhecimento como personalidade relevante da cidade e que mantinha boas relações com esses veículos e seus representantes. Queiroz era um membro bastante atuante do comércio local, tendo várias atividades paralelas à administração da Casa das Fazendas Pretas, participando de associações, eventos beneficentes, exposições oficiais, entre outras. ${ }^{22}$ Em suma, tanto o proprietário quanto a loja pareciam conhecidos da população local - pelo menos da parcela que frequentava o centro da cidade e do público leitor dos jornais de moda e variedades.

Uma nova mudança de endereço ocorre em 1896, quando a Casa das Fazendas Pretas passa a ocupar os números 23 e 25 na importante Rua dos Ourives. ${ }^{23}$ Vários impressos noticiam a inauguração com notas bastante elogiosas. A Gazeta de Noticias oferece uma pequena descrição de seu interior: uma loja grande, arejada e iluminada, de dois andares e mobília luxuosa. ${ }^{24} \bigcirc$ Jornal do Brasil, com muitos adjetivos direcionados ao empreendimento, fala da posição da Casa das Fazendas Pretas como um dos primeiros estabelecimentos desse tipo na América do Sul, permitindo aos brasileiros vestirem-se "parisiensemente". ${ }^{25}$

Pedro de Siqueira Queiroz faleceu pouco depois, em finais de julho de 1900, ${ }^{26}$ em Paris, vítima de uma "congestão pulmonar". ${ }^{27} \bigcirc$ corpo foi embalsamado e transportado para o mausoléu da família em Viena do Castelo, em Portugal, sua cidade natal. ${ }^{28}$ No Rio de Janeiro, em sua homenagem, rezou-se uma missa de sétimo dia na Igreja São Francisco de Paula, na qual estiveram presentes diversas personalidades e membros do comércio e da imprensa. ${ }^{29}$ Representando a família, estava no Brasil apenas Pedro de Siqueira Queiroz Filho, que, já nessa época, ajudava o pai com os negócios e se envolvia com atividades do comércio 
carioca. ${ }^{30} \mathrm{Em}{ }^{\circ}$ de agosto do mesmo ano, de acordo com documento da Junta Comercial encontrado no Arquivo Nacional, o filho passava a responder tanto pela firma Pedro de Siqueira Queiroz \& C. ${ }^{31}$ quanto pela Casa das Fazendas Pretas, além de assumir o nome do pai. ${ }^{32}$ Com a nova direção, vinham também outros desafios e possibilidades de crescimento para a loja.

\section{A CASA DAS FAZENDAS PRETAS NO CONTEXTO DE MODERNIZAÇÃO DO RIO DE JANEIRO}

Após a morte do fundador e de uma breve passagem pela Rua do Ouvidor, na qual, segundo nossos levantamentos, a loja funcionou por pouco mais de um ano, ${ }^{33}$ Queiroz Filho planejou um salto decisivo na história da Casa das Fazendas Pretas: investiu em seu deslocamento para a Avenida Central, hoje Avenida Rio Branco, ${ }^{34}$ principal via do centro da cidade. A inauguração foi em 14 de abril de 1906. $\bigcirc$ majestoso edifício de quatro andares, com vitrines e elevador próprio, na esquina com a Rua Sete de Setembro, tornou-se uma referência para o Rio de Janeiro do início do século XX. Pela ousadia, Pedro foi chamado de "espírito inventivo, comparável aos dos homens que fizeram a grandeza norte-americana". ${ }^{35}$ Na Gazeta de Noticias, lemos detalhes sobre o impactante empreendimento:

\section{Fazendas Pretas}

Inaugurou-se hontem, na Avenida Central, o novo edificio da conhecida Casa das Fazendas Pretas.

De um luxo digno de seus freguezes, a Casa das Fazendas Pretas, na esquina da rua Sete de Setembro, está enriquecida com um completo sortimento de fazendas, modas, confecções e armarinho.

Nas vitrinas destacam-se, além de outras figuras de cera, as da Cavallièri e Ottèro, de uma semelhança extraordinária. Fazendas das mais finas ostentam-se por todos os lados nas ricas armações.

Visitamos os quatro andares, para os quaes há um elegante e solido elevador, que infelizmente ainda não póde funccionar, por falta de corrente electrica alternativa; brevemente, porem, a Casa das Fazendas Pretas poderá apresentar ás famílias mais este attestado da sua vontade de servilas.

Não é preciso recordar aqui que a Casa das Fazendas Pretas se encarrega de todo e qualquer serviço de sua especialidade: para isso lá estão optimos empregados, sob as ordens do Sr. Pedro de Siqueira Queiroz, proprietário, incansável de solicitude. tos. Sabemos apenas que Rosina morreu com 4 anos, em 1886 (O PAIZ, 1886, p. 1), e Manuel, ainda bebê, em 1887 (JORNAL DO COMMERCIO, 1887, p. 7). O mesmo impresso, três dias depois, dá que a morte ocorreu aos quatro meses, por "eclampsia" - a grafia do nome do negociante aparece como Pedro Siqueira de Queiroz.

21. Jornal do Commercio, $1^{\circ}$ out. 1891, p. 10. Manteve-se a grafia original.

22. Pedro de Siqueira Queiroz participava ativamente de reuniões e associações, era benfeitor em obras de caridade (DIARIO DE NOTICIAS, 1885, p. 2), expôs seus produtos em eventos como a Exposição Nacional no Salão Imperador Pedro II (DIARIO DO COMMERCIO, 1888 , p. 2), foi presidente da Associação dos Empregados no Commercio do Rio de Janeiro entre 1883 e 1884 (ALMANAK ADMINISTRATIVO, MERCANTIL E INDUSTRIAL DO RIO DE JANEIRO, 1883, p. 1166; GAZETA DE NOTICIAS, 1883 , p. 2), foi suplente na diretoria do grupo de investidores que abriu o "Banco da Bolsa" (A TRIBUNA, 1890 , p. 2; NOVIDADES, 1890 , p. 3; O CRUZEIRO, 1890, p. 3), tornou-se o representante no Brasil da cerveja francesa produzida na Brasserie de Saint-Germain, pertencente à firma Cirier-Pavard, (JORNAL DO COMMERCIO, 1889, p. 6), foi sócio em loja de armarinhos (JORNAL DO COMMERCIO, 1888, p. 5) e foi proprietário e importador de inúmeros cavalos que corriam no Jockey Club (A NOTICIA, 1895 , p. 3; DIARIO DE NOTICIAS, 1893 , p. 2; GAZETA DA TARDE, 1895, p. 2).

23. É possível que tal local fosse o casarão histórico da antiga sede do Arquivo Nacional, prédio anteriormente ocupado pelos Terceiros da 
Ordem do Carmo, conforme matéria de Ignez Araújo de 1937 para a Revista O Observador Econômico e Financeiro. No entanto, as datas não coincidem com os anúncios da Casa das Fazendas Pretas naquele endereço (ARAUJO, 1937).

24. Gazeta de Noticias, 24 mar. 1896, p. 1. Manteve-se a grafia original. Em 6-7 de abril de 1896, o Jornal do Commercio também noticiou a mudança na primeira página.

25. Jornal do Brasil, 3 jul. 1896, p. 2.

26. Não foi localizada nenhuma nota de falecimento com a data exata da morte, e nos convites para a missa de sétimo dia, publicados pela imprensa, não fica claro se teria ocorrido em 27 ou 28 de julho.

27. O Paiz, 18 ago. 1906, p. 2.

28. Cf. A Noticia, 3-4 ago. 1900, p. 2.

29. Ibid.; Cf. Cidade do Rio, 3 ago. 1900, p. 3 .

30. Pedro Filho já era membro da Associação dos Empregados no Commercio do Rio de Janeiro (GAZETA DE NOTICIAS, 1899, p. 4).

31. "Declaração" feita na Junta Commercial. Coleção Junta Comercial, livro 38, registro 9.563, 1901.

32. A nota pelo $35^{\circ}$ aniversário da loja confirma a adoção, pelo filho, do nome do pai após sua morte (O PAIZ, 1906, p. 2).

33. Não obtivemos maiores informações sobre a configuração da loja nesse período. Tudo leva a crer que foi uma instalação temporária, entre novembro de $1904 \mathrm{e}$ dezembro de 1905, na Rua do Ouvidor, número 104.
Esse cavalheiro, de uma força de vontade extraordinária - attesta-o a mudança para o luxuoso edificio da Avenida Central - teve a amabilidade de nos acompanhar pelos quatro andares, e no ultimo, com uma taça de champagne na mão, brindou á prosperidade da Gazeta; esta, por sua vez, the desejou que continuasse a merecer a confiança do publico, que saberá corresponder aos seus intelligentes esforços. ${ }^{36}$

A nota é eloquente a respeito do patamar alcançado pela loja: além do novo e simbólico endereço, ressalta a magnitude das instalações (temporariamente prejudicadas pela falta de corrente elétrica) e a extravagante vitrine com figuras de cera ostentando as mais finas fazendas. Também exalta suas continuidades, como a qualidade dos serviços atrelados ao luto e o bom relacionamento do dono com a imprensa (que recebe a Gazeta pessoalmente para um tour com direito a brinde no finall.

O modelo de negócios desenvolvido ao longo dos anos pela Casa das Fazendas Pretas, que culmina no admirável empreendimento da Avenida Central, parece emular desde seu início o formato das lojas de departamentos, que se proliferaram na Europa a partir da década de 1850. ${ }^{37}$ No Brasil, as primeiras aparecem na década de 1870 em cidades como o Rio de Janeiro e Belém do Pará, que na segunda metade do século XIX vivenciavam um momento de prosperidade econômica e cultural ${ }^{38}$ - fosse pela importância política, no caso da primeira, ou pelos ciclos extrativistas, como a segunda. Na capital carioca, considera-se que a pioneira do gênero foi a Notre-Dame de Paris, aberta em 1848, na Rua do Ouvidor; 39 em seguida veio a Parc Royal, em 1873. Podemos imaginar, portanto, que Pedro de Siqueira Queiroz conhecia o formato, em sua configuração europeia ou brasileira, e pode tê-lo replicado em sua loja.

É significativo o surgimento dessas lojas como parte do processo de modernização do Rio de Janeiro, isto é, de sua transição de cidade colonial e rural, cujo comércio é incipiente e a vida social quase inexistente, ${ }^{40}$ para um grande centro urbano, com espaços públicos de sociabilidade, uma elite de hábitos afrancesados, eventos repletos de cerimoniais, comércio de massa e economia de caráter capitalista industrial. A Casa das Fazendas Pretas acompanhou esse desenvolvimento: mesmo com suas mudanças de endereço, sempre se instalou em logradouros estratégicos e próximos ao centro comercial, como a Rua da Quitanda, a Rua dos Ourives, a famosa e importante Rua do Ouvidor e, especialmente, o símbolo da reestruturação da capital, a Avenida Central: vias que foram cenários da vida elegante da "boa sociedade" 41 carioca e palco do desenvolvimento das novas práticas de consumo no Brasil, próprias do fim do Oitocentos e da passagem para o século XX. ${ }^{42}$ 
As lojas de departamento, segundo Richard Sennett, se caracterizariam pelo grande volume de mercadorias exposto e vendo por uma pequena margem de lucro, com preços fixos e claramente assinalados, e pela possibilidade de o público entrar apenas para olhar as mercadorias que estão ao alcance de suas mãos, sem a obrigatoriedade da compra. De acordo com Bonadio, a esta definição das lojas de departamento

é possível acrescentar ainda a presença de vitrines de vidro, a divisão por especialidade, o conceito de compra como "aventura divertida", na qual a cortesia, as novidades, a exibição cuidadosa e a circulação despreocupada tornavam a aquisição da mercadoria um mergulho em uma fantasia sociocultural. ${ }^{43}$

Esse "caráter de espetáculo" é deliberadamente promovido pelos proprietários, afirma Sennett, que arranjam seus produtos de maneira decorativa e inusitada, estimulando a imaginação do comprador a revestir esses objetos de significação pessoal acima e para além de sua utilidade. ${ }^{44}$

No caso da Casa das Fazendas Pretas, apesar de não se assumir, seja em seus anúncios, seja nas notas publicadas nas revistas, como uma loja de departamentos, diversos aspectos a aproximavam dessa configuração. A importação de grandes quantidades de tecidos próprios para o luto e sua conseguinte venda por preços pré-determinados e anunciados nas revistas seria um deles, como confirma o reclame da edição de 6 de julho de 1877 do Jornal do Commercio, que oferece vários tipos de panos cortados em côvados ${ }^{45}$ por valores fixos, que seriam aplicados no local. $\bigcirc$ cliente, de antemão, saberia que vinte côvados de gorgorão eram vendidos a 30 mil réis (mesmo valor da nobreza e da seda), vinte côvados de cassa de lã, a 8 mil reis (assim como a musselina) e vinte côvados de chita preta, a 6 mil réis. ${ }^{46} \bigcirc$ anúncio ressalta a variedade de tecidos e artigos em geral (incluindo chapéus de escomilha, luvas, leques, lenços, toucas e véus para viúvas) para o luto à venda, tudo "a preços reduzidos" e fornecidos "com a maior presteza". ${ }^{47}$ Periodicamente, a loja realizava grandes queimas de estoque, com abatimentos de 25\%,40\% ou a "preços nunca vistos" por ocasiões como a Semana Santa, o Natal, o fim do ano, seu aniversário ou uma de suas mudanças de endereço.

A publicidade da Casa das Fazendas Pretas cria o falso paradoxo do estabelecimento de luxo que vende seus artigos a preços módicos e tabelados que, no entanto, é característico das lojas de departamentos. Gorberg, em seu estudo sobre a Parc Royal, que utilizava a mesma estratégia, comenta que
34. A mudança do nome da avenida ocorreu em 15 de fevereiro de 1912, em homenagem ao barão de Rio Branco, falecido naquele ano.

35. O Jornal, 18 ago. 1921 , p. 2, e Correio da Manhã, 18 ago. 1921, p. 4.

36. Gazeta de Noticias, 15 abr. 1906, p. 5. Manteve-se a grafia original.

37. Oficialmente, a primeira delas a ser aberta teria sido a Bon Marché, em Paris, inaugurada em 1852, embora esse modelo de negócio estivesse em desenvolvimento antes (SENNETT, 1988). Nas décadas de 1870 e 1880, surgiram casas do tipo na França e na Inglaterra, em capitais como Berlim e Amsterdã, e logo o modelo chegou a outros continentes, em países como Japão e Estados Unidos (GORBERG, 2013).

38. Cf. Bonadio (2007).

39. Segundo Bonadio, algumas "pré-lojas" de departamento já poderiam ser encontradas no centro do Rio de Janeiro a partir da década de 1820 (2007, p. 58). Jeffrey Needell comenta que a Notre-Dame de Paris foi fundada em 1848 como um protótipo de loja de departamento, que só se torna de fato uma na década de 1870 ( 1987 , p. 288 , nota de rodapé número 20 ).

40. Cf. Gorberg, op. cit.

41. Segundo a historiadora Maria do Carmo Rainho, que cunhou a expressão, essa era a camada que, após a chegada da Corte no Rio de Janeiro, buscou se igualar à burguesia europeia e à aristocracia portuguesa adotando valores e modos europeus, civilizando os costumes, eliminando hábitos coloniais e manifestando, por meio da aparência, o quanto se distinguia dos 
outros estratos. Ou seja, para Rainho, pertencer à "boa sociedade" não se vinculava, necessariamente, a ter riqueza e poder: "o perfil dos membros da 'boa sociedade' é restringido, pois para ser caracterizado como tal não bastam a posse da riqueza, o acesso ao consumo de determinados bens ou o exercício do poder, sendo preciso também se destacar pelo requinte das maneiras, pelo polimento dos costumes e, especialmente, pela maneira de apresentar-se socialmente" (RAINHO, 2002, p. 17).

42. A metáfora do espaço público como teatro é explorada e aprofundada por Sennett (1988).

43. Bonadio (2007, p. 48).

44. Sennett, op. cit., p. 183.

45. Antiga unidade de medida empregada em Portugal e no Brasil até a introdução do sistema métrico; equivalia a 3 palmos, ou aproximadamente 68 centímetros.

46. Cf. Jornal do Commercio, 6 jul. 1877, p. 7.

47. Ibid.

48. Gorberg, op. cit., p. $72-$ 73.

49. O Metropolitan Museum de Nova York mantém um exemplar dos espartilhos da Maison Leóty contemporâneo aos anunciados pela Casa das Fazendas Pretas, que pode ser visto em: <https://bit.ly/39Gv7IK>.

50. Jornal do Commercio, 3 set. 1890 , p. 9. No último item anunciado, lê-se: "Colletes Leoty: os melhores e mais afamados colletes que se usão em Pariz".

51. Cf. Bonadio (2007).

52. Needell (1987, p. 36, 39, tradução nossa).
O alarde dos preços baixos, constante da comunicação da loja, revela um apelo popularesco, que manteve-se em dualismo à edificação de uma imagem elitista [...]. O Parc Royal externava uma imagem de requinte, beleza e sofisticação que o tornava atraente às elites, ao mesmo tempo em que fazia um convite ao consumo extenso a todos. ${ }^{48}$

Poderíamos aplicar a mesma lógica ao modus operandi da Casa das Fazendas Pretas que, por se posicionar no mercado como "a única de seu gênero", propunha-se a atender a todos os públicos em sua demanda por trajes e acessórios de luto e meio-luto, ao mesmo tempo que se apresentava como local elegante e sóbrio (até mesmo pelo nicho em que operava), com mercadorias importadas e fornecedora dos últimos lançamentos da moda europeia.

Com a rápida consolidação da Casa das Fazendas Pretas no comércio de têxteis da cidade, passou a ser do interesse de seus proprietários diversificar a oferta de produtos sem descaracterizá-los nos aspectos que eram seu diferencial. As notas publicadas na imprensa, como vimos anteriormente, desde muito cedo mencionavam a disponibilização de "outros artigos e fazendas da moda" e a instauração de uma seção dedicada a roupas e tecidos coloridos. Por muitos anos, a Casa das Fazendas Pretas vendeu os "Colletes Leoty", espartilhos franceses feitos pela Maison Leóty, de Paris, ${ }^{49}$ como se pode conferir em anúncio no Jornal do Commercio de 3 de setembro de 1890.50 $\mathrm{O}$ item, longe de ser exclusivo do guarda-roupa de luto da época, era parte essencial do conjunto das chamadas roupas "de baixo", as roupas íntimas femininas.

Outro aspecto importante a ser considerado nessa comparação com as lojas de departamentos é o sistema de vendas de trajes da Casa das Fazendas Pretas. Num primeiro momento, eram feitos sob medida em suas oficinas de costura; posteriormente, passam a ser oferecidas também roupas prontas - um desenvolvimento que caracterizou as casas de departamentos e que indica o crescimento e a melhoria das confecções. ${ }^{51} \bigcirc$ nicho do comércio de luto exigia esses dois tipos de serviço, uma vez que a presteza na adoção do vestuário em cor preta por parte dos enlutados era observada e cobrada com mais rigor no decorrer da segunda metade do século XIX, como veremos mais adiante.

Não se pode esquecer o mais evidente vínculo entre a Casa das Fazendas Pretas e o modelo de lojas de departamentos, que é sua imponente instalação na Avenida Central. Segundo Jeffrey Needell, "nada expressa a belle époque carioca melhor do que a Avenida Central", planejada para ser um "monumento ao Progresso do Brasil". 52 A construção da via, inaugurada com grande solenidade no dia 15 de novembro de 1905, ${ }^{53}$ fez parte da transformação radical do centro da cidade, orquestrada pelo prefeito Francisco Pereira Passos (1902-1906). 
Inspirado pelo barão de Haussmann, responsável pelas reformas em Paris entre 1853 e 1870, Passos decidiu fazer do Rio de Janeiro a "metrópole-modelo da modernidade". ${ }^{54}$ Além do novo traçado e do alargamento da Avenida Central, que, com seus quase 2 mil metros de comprimento por 33 metros de largura, se tornaria a espinha dorsal da nova e repaginada urbe, faziam parte do projeto a revitalização geral do centro, o aumento das ruas, melhoria da iluminação e ventilação, além de incrementos no saneamento, a construção de jardins e parques, embelezamento das praças existentes, edificação de prédios em estilo eclético (conforme preconizava a École des Beaux-Arts), entre outros. ${ }^{55}$

A Avenida Central deveria ser o cartão postal da moderna capital da República, ostentando os símbolos da grandiosidade e da funcionalidade de uma jovem metrópole. Para isso, em contraste com seu entorno, exibiria de ponta a ponta construções majestosas, que incluíam os prédios públicos do Theatro Municipal, da Biblioteca Nacional, Palácio Monroe e Escola Nacional de BelasArtes. "Os particulares, também impactantes, tiveram seus projetos submetidos à aprovação de um júri, obedecendo a um critério seletivo para manter a unidade visual das fachadas. Com guarnições de ferro fundido e vidro, essas construções formavam um grande monumento ao progresso do país [... ]", afirma Gorberg. ${ }^{56}$

Muitos desses colossos foram ocupados por lojas, que faziam da Avenida Central um espaço de lazer e entretenimento onde era possível admirar as vitrines e, eventualmente, se deixar conquistar pelo convidativo apelo de suas mercadorias, entrar nos arejados e bem iluminados templos do consumo e flanar despreocupadamente por entre as prateleiras. Entre esses estabelecimentos estava a Casa das Fazendas Pretas, instalada na esquina com a rua Sete de Setembro, em 1906, em um edifício em estilo eclético com predominância de elementos neoclássicos, assinado pelo arquiteto Gatell y Solá. ${ }^{57} \bigcirc$ fotógrafo Marc Ferrez 11843 1923), que registrou o processo de construção da via e as fachadas de seus principais prédios, reproduziu as fotografias em litogravuras em seu livro sobre a Avenida Central dos anos 1903 a 1906, nos proporcionando uma rara oportunidade de visualizar a aparência exterior da Casa das Fazendas Pretas (Figura 1).
53. Houve duas inaugurações, segundo Needell: uma em 7 de setembro de 1904 , outra em 15 de novembro de 1905 (1987, p. 38).

54. Gorberg, op. cit. p. 25.

55. Cf. Gorberg, op. cit. e Needell, op. cit., p. 34-36. O "processo civilizador", para usar a já consagrada expressão cunhada por Norbert Elias, pelo qual passava o centro do Rio de Janeiro, incluía vetar atividades populares, como a venda de comidas em barracas, a exposição de carne crua na porta dos açougues, cuspir nas ruas, vender leite de porta em porta, criar porcos dentro dos limites da cidade e comemorar o entrudo ou realizar cordões na época do Carnaval.

56. Gorberg, op. cit.

57. Cf. Ferrez (1907) 


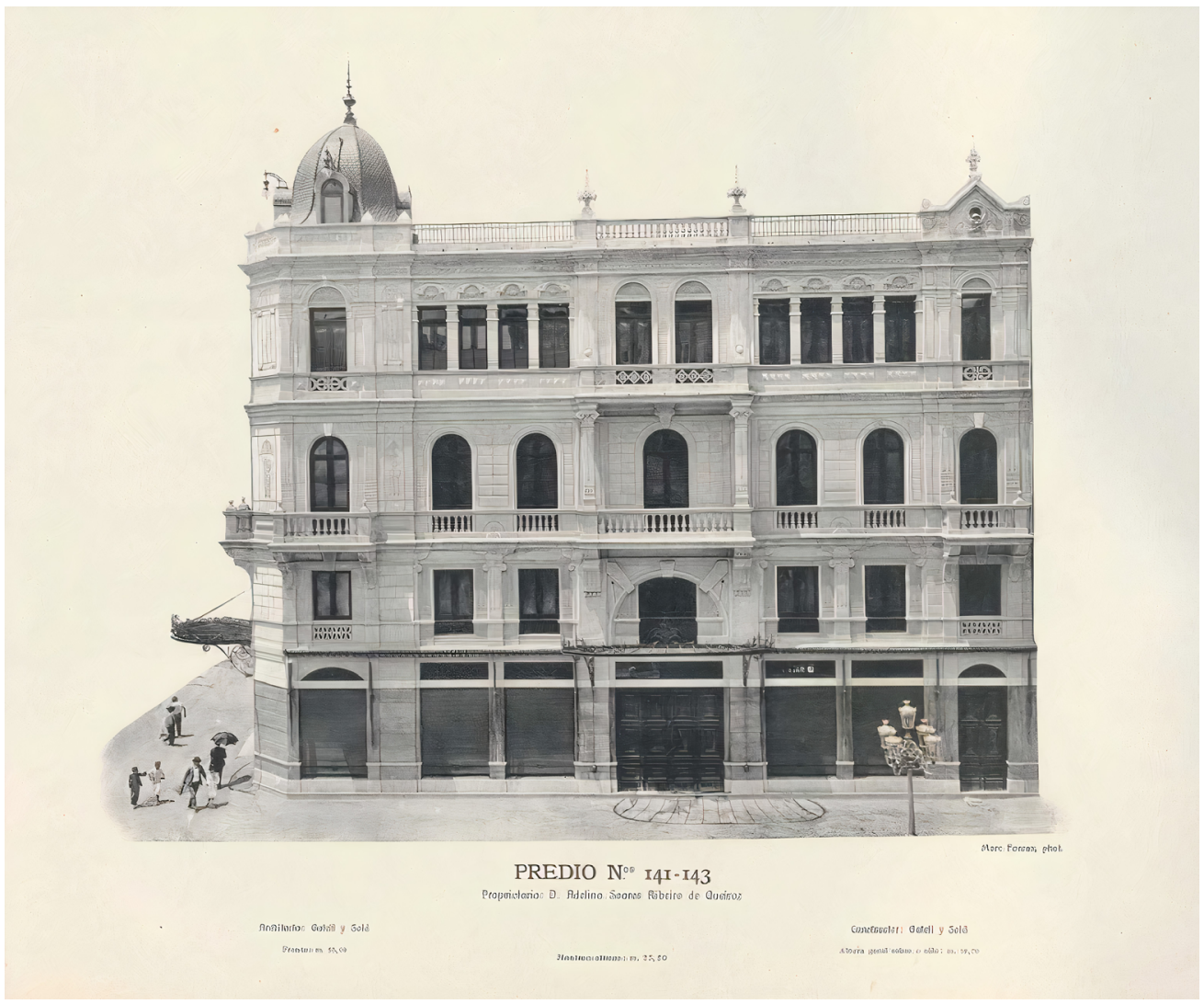

Figura 1 - Fachada da Casa das Fazendas Pretas vista da Avenida Central. Fonte: Ferrez (1907).

Lá, a casa viveu sua fase de ouro. Reconhecida, a partir de então, como grande magazine de modas, ultrapassando sua função primeva de fornecedora de lutos, disputava a atenção da clientela com concorrentes de peso, como a Parc Royal. Para isso, se valia do impressionante edifício de quatro andares, do elevador elétrico e de suas largas vitrines de vidro no térreo. A estratégia era conhecida das lojas de departamentos:

A arquitetura dos magazines incorporou uma certa magnitude, facilitando a livre circulação pelos espaços e a visibilidade dos produtos, somados a uma impressão estética que causava a admiração na clientela que desfrutava daquele local.

As vitrines, incorporadas a partir da modernidade, provocaram impacto à época de sua disseminação, no final do século XIX. [...] amplificavam o apelo visual dos produtos, transformando os passantes em potenciais clientes $[\ldots] .{ }^{58}$ 
Em sua primeira localização, no sobrado do número 15 da Rua da Quitanda, a Casa das Fazendas Pretas já empregava expositores com vidraças na parte interna do estabelecimento, em seu corredor principal. ${ }^{59}$ Entretanto, é no prédio da Avenida Central que a vitrine, essa inovação de 1885,60 seria utilizada em sua plenitude. Suas "portas e vitrinas sumptuosas" "6l davam para a badalada via e exibiam "figuras de cera" e "ricas armações", nas quais se ostentavam "fazendas das mais finas". ${ }^{2}$ Tal configuração provavelmente foi responsável por gerar uma interessante associação, feita no jornal A Imprensa, de 17 de julho de 1912, com o "Paraíso das Damas", loja de departamentos fictícia que dá nome ao famoso romance de Émile Zola, publicado em 1883 :

Também, quem é que hoje não conhece a Casa das Fazendas Pretas? De facto, não há quem passe pela Avenida, sem se sentir attrahido pelo bom gosto, pela suprema elegância que se nota sempre nas montras da Casa das Fazendas Pretas. É que nenhum outro estabelecimento possue a arte do étalage, arte subtil e difficil de que Zola nos fala no seu "Bonheur des Dames", como sendo quase uma sciencia e a própria exteriorização do bom gosto de um estabelecimento. ${ }^{63}$

O dicionário Larousse define étalage ${ }^{64}$ como a exposição das mercadorias à venda em um estabelecimento. No contexto empregado, a "arte do étalage" poderia ser entendida como a habilidade em mostrar os produtos com ostentação, exibi-los de forma prazerosa e presunçosa. A comparação é das mais contundentes - basta lembrar o choque da protagonista de Zola, Denise, ao se deparar com o Paraíso das Damas pela primeira vez: "esse magazine encontrado bruscamente, esse edifício gigantesco para ela, enchia-lhe o coração, deixava-a paralisada, emocionada, curiosa, esquecida do resto." 65 Após um longo silêncio enquanto admirava as vitrines, a fachada, os mostruários na entrada com os mais finos tecidos e os mais extravagantes bibelôs, Denise finalmente exclama: "Isso sim que é uma loja!". 60 No grande espetáculo urbano encenado na Belle Époque - período em que, no Brasil, se misturavam tradições longínquas e os novos fenômenos da história cultural do país -, 67 lugares como a Casa das Fazendas Pretas celebravam a produção industrial e o consumo em larga escala, seduziam a clientela ávida por novidades e embelezavam as vias por onde desfilava a burguesia triunfante.
59. Conforme nota publicada na seção "Especiais" do Correio do Brazil de 18 de janeiro de 1872 , p. 2.

60. Cf. Bonadio (2007)

61. O Jornal, 18 ago. 1921 , p. 2.

62. Gazeta de Noticias, 15 abr. 1906 , p. 5 .

63. Nota de parabenização pelo aniversário da loja publicada n'A Imprensa, 17 de agosto de 1912 , p. 4. Manteve-se a grafia original.

64. Étalage (c2021).

65. Zola, 2008, p. 32.

66. Id., p. 31.

67. Cf. Needell, op. cit. 
68. Cf. Jornal do Commercio, 14 de fevereiro de 1876 , dentre muitos outros exemplos.

69. Cf. Jornal do Commercio, 5 de abril de 1878 , p. 4 ; 6 de junho de 1878 , p. $8 ; 30$ de janeiro de 1879, p. 7 .

70. O gorgorão poderia ser em seda ou misto de seda e algodão (TAYLOR, 1983a, p. 294).

71. Cf. Cumming, Cunnington e Cunnington (2010).

72. Cf. Italiano et al., op. cit. 73. Cf. Cumming, Cunnington e Cunnington, op. cit.

74. Cf. Boucher (2010).

75. Ibid.

\section{ANÚNCIOS, PRODUTOS E SERVIÇOS}

Apesar da longa trajetória da Casa das Fazendas Pretas, que a coloca como testemunha do processo de modernização do Rio de Janeiro e de consolidação das elites burguesas nos centros urbanos brasileiros, vamos nos concentrar neste momento em sua atuação nos anos finais do século XIX até a virada para 0 século $X X$, recorte que nos interessa a respeito das práticas vestimentares relativas ao luto.

A grande diversidade de itens que compunha a etiqueta de luto à venda na Casa das Fazendas Pretas revela a complexidade do tema. Absolutamente tudo poderia existir em sua "versão para luto", especialmente para meio-luto ou luto aliviado, a fase em que adornos e acessórios são permitidos (dentro de certos limites e seguindo determinados atributos). Entre praticamente todos os anúncios, destacamos tal característica no do dia 9 de abril de 1879, que ocupou o topo de duas páginas do Jornal do Commercio oferecendo, entre muitas curiosidades, leques pretos "com algumas pintas de mofo" (que, possivelmente trazidos em navios da Europa, sofreram a ação da umidade), paletós de merinó "para senhoras muito gordas" (o que talvez demonstre a dificuldade desse público em encontrar roupas prontas adequadas ao seu tamanhol e "objectos pretos" em geral, como chapéus de sol, colares, pulseiras, brinco-gravatas, fichus, fitas, flores, véus, livros de missas, entre outros.

No século XIX, a Casa das Fazendas Pretas tinha como carro-chefe os tecidos de seda trazidos da França (com destaque para a seda proveniente da cidade de Lyon), ${ }^{68}$ especialmente os gorgorões. ${ }^{69} \bigcirc$ gorgorão de seda ${ }^{70}$ era bastante consumido à época: robusto e de alta qualidade, ${ }^{71}$ se caracteriza pelas nervuras com aspecto de canaleta ${ }^{72}$ ou cordão. ${ }^{73}$ Tingido de preto, foi muito usado em trajes de luto e de meio-luto.

Sabe-se que a cidade francesa de Lyon, pelo menos desde o Antigo Regime, era conhecida por suas sedarias, principalmente a partir do reinado de Luís XIV. O amplo consumo do tecido pela corte fez surgir uma produção que desse conta de tal demanda, e a região de Lyon se especializou em atendê-la com consideráveis incentivos do governo (como a subvenção da cultura da amoreira [cujas folhas são o principal alimento do bicho-da-seda], encomendas do Estado e taxação da seda estrangeira)..$^{74} \bigcirc$ desenvolvimento da técnica e os delicados desenhos feitos à mão pelos artistas instalados na cidade fizeram a fama da seda de Lyon, usada pelos nobres e pelo próprio rei. No Oitocentos, as sedarias de Lyon passam a exportar para muitos países, com destaque para os Estados Unidos, ${ }^{75}$ aproveitando a voga 
do surgimento da Alta Costura na segunda metade do século, que alimentava a aura em torno da moda francesa. $\bigcirc$ conceito "seda de Lyon" transmitia credibilidade, qualidade e luxo. Na Casa das Fazendas Pretas, pelo menos na década de 1870, eram vendidas as sedas dos fabricantes Bonnet, Ponson e Jaubert. ${ }^{76}$

É necessário ainda mencionar o importante papel desempenhado pela oficina de costura da loja. Afinal, a rapidez na feitura dos trajes sob medida era questão crucial na etiqueta lutuosa da segunda metade do século XIX, fazendo com que o tempo de produção das peças se tornasse um imperativo. Esperava-se que todo o guarda-roupa estivesse adaptado para a nova circunstância em um prazo curtíssimo - especialmente no caso das mulheres e principalmente nas elites e classes médias, as quais se pressupunha que tivessem condições para tal. Taylor explica, em relação ao costume inglês, que até a abertura dos primeiros estabelecimentos especializados, havia uma tolerância para a adaptação ao luto completo de no máximo oito dias. Por volta da década de 1860, no entanto, as lojas tiravam medidas, confeccionavam e entregavam os trajes em tão pouco tempo - às vezes, em questão de horas - que o crivo social se tornou ainda mais exigente. ${ }^{77}$

Poderíamos chegar a conclusão semelhante em relação aos serviços oferecidos pelo comércio carioca, cada vez mais acelerados, o que percebemos em diversos anúncios de modistas e lojas que aprimoraram a entrega do serviço de um dia para o outro, em 12 horas ou em até mesmo em 8 horas. 78 Uma família de posses não teria desculpas para não contratálos. $\bigcirc$ ideal seria que, já em suas primeiras aparições após o falecimento, seus membros estivessem seguindo as demandas do bom-tom à risca. A publicidade da Casa das Fazendas Pretas dava ênfase a esse quesito constantemente, como se pode conferir no anúncio de 6 de julho de 1877, publicado no Jornal do Commercio, no qual promete fornecer "com a maior presteza qualquer luto urgente."79 $\mathrm{Ou}$, ainda, o reclame no Almanak Laemmert de 1875, que promete a entrega do luto completo em 48 horas. ${ }^{80}$

Tendo em vista que os anúncios apareciam em publicações que eram também consumidas, ainda que em menor escala, pelas classes médias e baixas, é interessante notar alguns serviços direcionados para esse público, como o tingimento em preto por tinturarias e a venda de peças prontas. Na tentativa de enaltecer essas opções, os anúncios apelavam para sua "excessiva barateza" e divulgavam reconhecimento em concursos, como era o caso da Tinturaria do Commercio, que prometia tingir para luto em 24 horas e ostentava prêmios na Exposição Nacional de 1873 e na Exposição Industrial de 1878.81 Ao paletó fluminense, loja dedicada ao vestuário masculino, vendia roupas prontas por valores bastante abaixo dos praticados para encomendas sob medida (30\% a 40\% menos), incluindo ternos em merinó, peças diversas em casimira preta e fumo para chapéu. ${ }^{82}$
76. Cf. Jornal do Commercio, 18 de agosto de 1878 , p. 2; e Gazeta de Noticias, 11 de março de 1876 , p. 3.

77. Taylor (1983a).

78. São exemplos os anúncios de Mme. E. Creten intitulado "luto em 24 horas", publicado no Almanak Administrativo, Mercantil $e$ Industrial do Rio de Janeiro (1877, p. 94), e do Bazar Elegante de Goulart \& Irmão, que prometia trajes confeccionados em 8, 12 ou 24 horas (1882, p. 231).

79. Jornal do Commercio, 6 jul. 1877, p. 7.

80. Almanak Administrativo, Mercantil e Industrial do Rio de Janeiro (1875, p. 101).

81. Id., 1885, p. 2099.

82. Anúncio da Ao Paletó Fluminense no Almanak Administrativo, Mercantile Industrial do Rio de Janeiro, (1876, p. 861). 
83. Taylor (1983a).

84. Taylor (1983, p. 132) comenta ainda que havia anúncios nas revistas e jornais (colunas de Articles Wanted) propondo a troca de roupas de luto por roupas coloridas.

85. Como se pode verificar no anúncio da Notre-Dame de Paris publicado no $A l$ manak Administrativo, Mercantil e Industrial do Rio de Janeiro (1860, p. 41) e em recibos de compras de artigos de luto na coleção de objetos pessoais de dona Maria Amália Ferreira Lage, no Museu Mariano Procópio, em Juiz de Fora, Minas Gerais.

86. "Segundo Michelle Perrot, em 1801 a expectativa de vida era de 30 anos. Em meados do século passou para 38 para os homens e 41 para as mulheres. Hobsbawm afirma que a esperança de vida média nos anos 1880 nas principais regiões desenvolvidas Bélgica, Grã-Bretanha, França, Massachusetts, Holanda e Suíça - era de apenas 43-5 anos e menos de 40 na Alemanha. As maneiras simples de prevenção de doenças, muitas delas baseadas no controle básico da higiene na preparação de alimentos ou nos partos não eram uma praxe, assim como a frequente utilização de medicamentos duvidosos de origem caseira aumentavam as chances de falecimento prematuro. Não era nada incomum que se estendesse de um período de luto para outro, os indivíduos passavam um bom tempo de suas vidas cobertos de negro." (SCHMITT, 2010, p. 115).
Taylor comenta que o comércio de roupas de luto usadas também era bastante expressivo no contexło geral dos consumos relacionados ao luto no século XIX. A prática era fomentada pela crença, espalhada pelas próprias confecções e fábricas de artigos pretos, de que guardar os trajes após terminado um luto trazia má sorte. ${ }^{83}$ Além disso, até que viesse um novo luto, o estilo das peças estaria ultrapassado. ${ }^{84}$ Assim, se desfazer dessas roupas criava um comércio não oficial e personalista, divulgado no boca a boca ou em anúncios do tipo classificados nas revistas. A autora afirma que apenas uma minoria de mulheres podia adquirir os elegantes e caros trajes sugeridos pelas revistas em todas as etapas do luto, e que as classes médias e baixas britânicas tentavam adaptar as ideias com o que estava ao seu alcance para parecerem "decentes" nos funerais com suas roupas simples de lã e algodão, pois sofriam com a mesma vigilância dedicada às elites, porém exercida por seus pares. A possibilidade de usar roupas de melhor qualidade, ainda que de segunda mão, era, portanto, bastante aproveitada. Não foram encontradas evidências dessa prática no Brasil, ou mais especificamente no Rio de Janeiro, mas é possível supor que ela também se estabelecera por aqui.

Antes que se tenha a impressão de que o comércio de artigos de luto fosse uma extravagância, disponível em poucas e selecionadas lojas (como a Casa das Fazendas Pretas), há de se pontuar que estabelecimentos de médio e grande porte geralmente mantinham uma seção de luto lou, como também era conhecida, uma "seção de fazendas pretas"). Longe de ser algo escondido ou de difícil acesso, o conjunto dos materiais necessários ao luto, principalmente para a elite, provavelmente movimentava grandes valores, era complexo e de alta demanda. Mesmo lojas de departamento famosas e sofisticadas, como a Notre-Dame de Paris, anunciavam e vendiam luto. ${ }^{85} \mathrm{~A}$ demanda era frequente, pois passar pela experiência da perda de um ente querido não era algo excepcional. Em uma época em que os índices de mortalidade infantil eram altos (a cada vinte crianças, três morriam antes de completar o primeiro ano de vida) e a expectativa de vida girava em torno dos quarenta anos, não era nada incomum emendar um luto em outro. ${ }^{86}$

\section{VESTIR-SE DE LUTO NA CASA DAS FAZENDAS PRETAS}

Ainda que de maneira indireta, por meio da publicidade, a Casa das Fazendas Pretas ensinava suas clientes o que usar em seus lutos. Em algumas ocasiões, essa estratégia foi mais explícita, como no caso dos anúncios que incluíam tabelas com orientações para o guarda-roupa das viúvas ou para "qualquer 
senhora", que não fosse a viúva, mas que estivesse enlutada por outro parente. ${ }^{87}$ Apesar de seu aspecto publicitário, elencando produtos que certamente estavam à venda na loja, elas nos ajudam a considerar os itens eleitos como necessários para - luto das mulheres. A Figura 2 reproduz a tabela publicada em várias edições e diferentes jornais na década de 1880.88

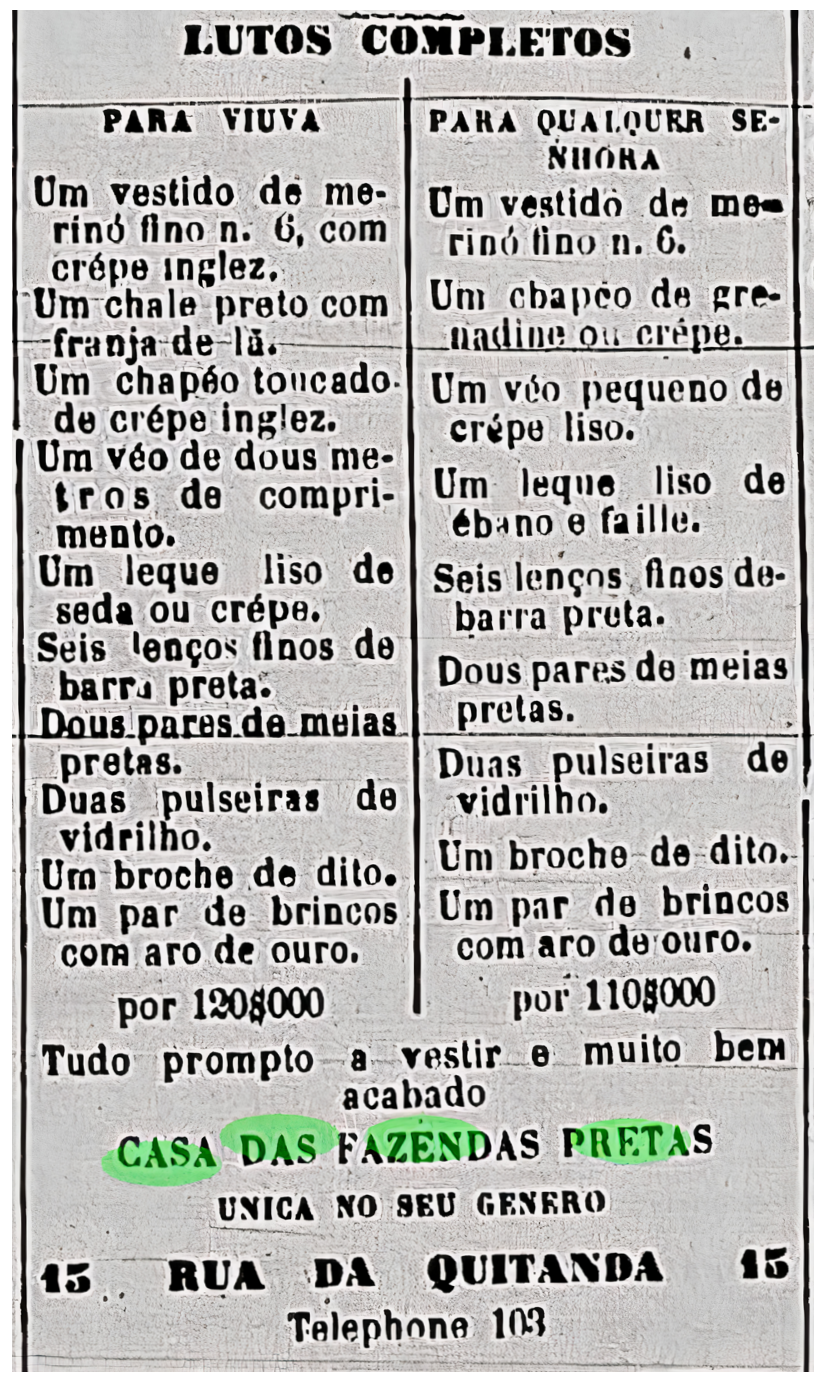

Figura 2 - Tabela de "Lutos completos. Para viúva/Para qualquer senhora". Fonte: Gazeta da Tarde (1887, p. 3).
87. A separação demonstra $o$ alto nível de exigência e rigor no luto da viúva (TAYLOR, 1983a).

88. São exemplos a Gazeta da Tarde (1887, p. 3), Novidades (28 de março de 1887 , p. 3) e Jornal do Commercio, de 12 de fevereiro de 1890 (p. 5).

89. Cf. Taylor (1983a).

As diferenças entre as duas colunas são sutis, mas cruciais. $\bigcirc$ mesmo vestido em merinó fino adequado a todos os lutos deveria ser adicionado de crepe, no caso da viúva. O crepe é o tecido por excelência do luto no século XIX: tradicionalmente feito em seda, era leve (podendo ser quase transparente), confortável e opaco (graças a processos industriais que removiam seu brilhol, utilizado em qualquer peça de roupa, nos chapéus e véus. ${ }^{89}$ De acordo com Taylor, 
90. Ibid., p. 203-204, tradução nossa.

91. Cf. Howarth e Leaman (2004).

92. Por exemplo, os glossários de História do vestuário no Ocidente (BOUCHER, 2010) e de Mourning dress (TAYLOR, 1983a) e o The dictionary of fashion bistory (CUMMING; CUNNINGTON; CUNNINGTON, 2010).

93. Cf. Boucher (2010, p. 457).

94. Cf. Cumming, Cunnington e Cunnington, op. cit., p. 26, tradução nossa.

95. Los Angeles County Museum of Art ([18--?]).

96. Boucher, op. cit., p. 459.

97. Cf. Cumming, Cunnington e Cunnington, op. cit.

98. Taylor (1983a). "[é] o crepe para luto que acima de tudo simboliza a viúva vitoriana de classemédia", 90 ou seja, era a fazenda mais utilizada e adequada para o luto, mais ainda para o da viuvez. A recomendação do crepe inglês também não era por acaso: a Inglaterra era a principal fornecedora do tecido reconhecida por sua qualidade e tradição, e algumas tecelagens fizeram verdadeiras fortunas com a produção e venda do crepe preto para o luto, como foi o caso da Courtaulds. ${ }^{91}$

$\bigcirc$ "chale preto com franja de lã", incluído apenas na primeira coluna, possivelmente serviria para encobrir ainda mais o corpo da viúva, de longe o tipo de enlutada mais fiscalizada. Evidência disso é a indicação de um véu de dois metros de comprimento para ela, contra "um véo pequeno de crepe liso" para as outras senhoras. Peça fundamental do luto, o véu era usado de maneira ostensiva, por vezes ocultando totalmente a identidade de quem o portava.

A sugestão do chapéu da viúva é em modelo "toucado". Não foi possível determinar com exatidão a qual formato a expressão se refere, mas, conforme as definições encontradas em obras de referência ${ }^{92}$ e imagens coletadas nas revistas e em sites de museus, entendemos que se trata ou do bonnet ou da capota. Ambos são peças bastante comuns no século XIX, cujas descrições se confundem. De maneira geral, são similares a toucas, confeccionados em tecido, como o crepe, a seda, a musselina, o tule e a renda, amarrados em nó ou laço de fitas ou faixas por baixo do queixo.

O quesito que motiva a discordância entre as fontes é a existência ou não da aba frontal. Boucher apresenta o bonnet como o toucado sem aba, ${ }^{93}$ assim como o The Dictionary of Fashion History: "geralmente um tipo de chapéu cuja parte traseira é ausente ou muito pequena, amarrado por fitas sob o queixo". 94 No entanto, o Museu de Arte do Condado de Los Angeles (Los Angeles County Museum of Art) 95 o categoriza como um modelo com aba frontal que contorna o rosto. Já a capota, para o mesmo Boucher, é "toucado de mulher cujas características eram envolver o coque e ter uma aba larga e envasada emoldurando o rosto"96 (explicação parecida com a encontrada no The dictionary of fashion history,, 97 enquanto o modelo repetidamente sugerido nas revistas femininas com esse nome é mostrado como um pequeno chapéu no topo da cabeça, cobrindo o coque, sem abas ou com bico sobre a testa. De qualquer maneira, o bonnet era um tipo de chapéu próprio para o luto, citado inúmeras vezes por Taylor ${ }^{98}$ e presente nas listas das peças de indumentária necessárias para tal ocasião publicadas por revistas inglesas.

Para ilustrar, a Figura 3 reproduz uma imagem publicada na edição de 30 de setembro de 1899 de A Estação, que mostra duas representações de mulheres enlutadas. A da direita usa um pequeno chapéu-capoła em bico, com véu longo 
anexado atrás, caindo nas costas. $\bigcirc$ grande xale debruado que cobre quase todo seu corpo e a saia lisa e simples do vestido, sem barrado ou folhos, indicam que seu traje é de luto fechado, possivelmente um luto de viúva (conforme a descrição na tabela da Casa das Fazendas Pretas). À esquerda, vemos outra figura feminina, com roupa ainda sóbria, mas mais decorada, provavelmente de meio-luto. $\bigcirc$ vestido com jaqueta é em tecido de trama grossa, com guarnição de vieses na saia formando três faixas; a blusa de gola alta é pregueada na frente. Seu véu disfarça apenas o rosto e é preso ao pequeno chapéu de abas curtas, enfeitado de laços - acessórios que estão de acordo com o sugerido na segunda coluna da tabela da Casa das Fazendas Pretas -, e em umas das mãos segura um lenço, olhando melancolicamente na direção do leitor.

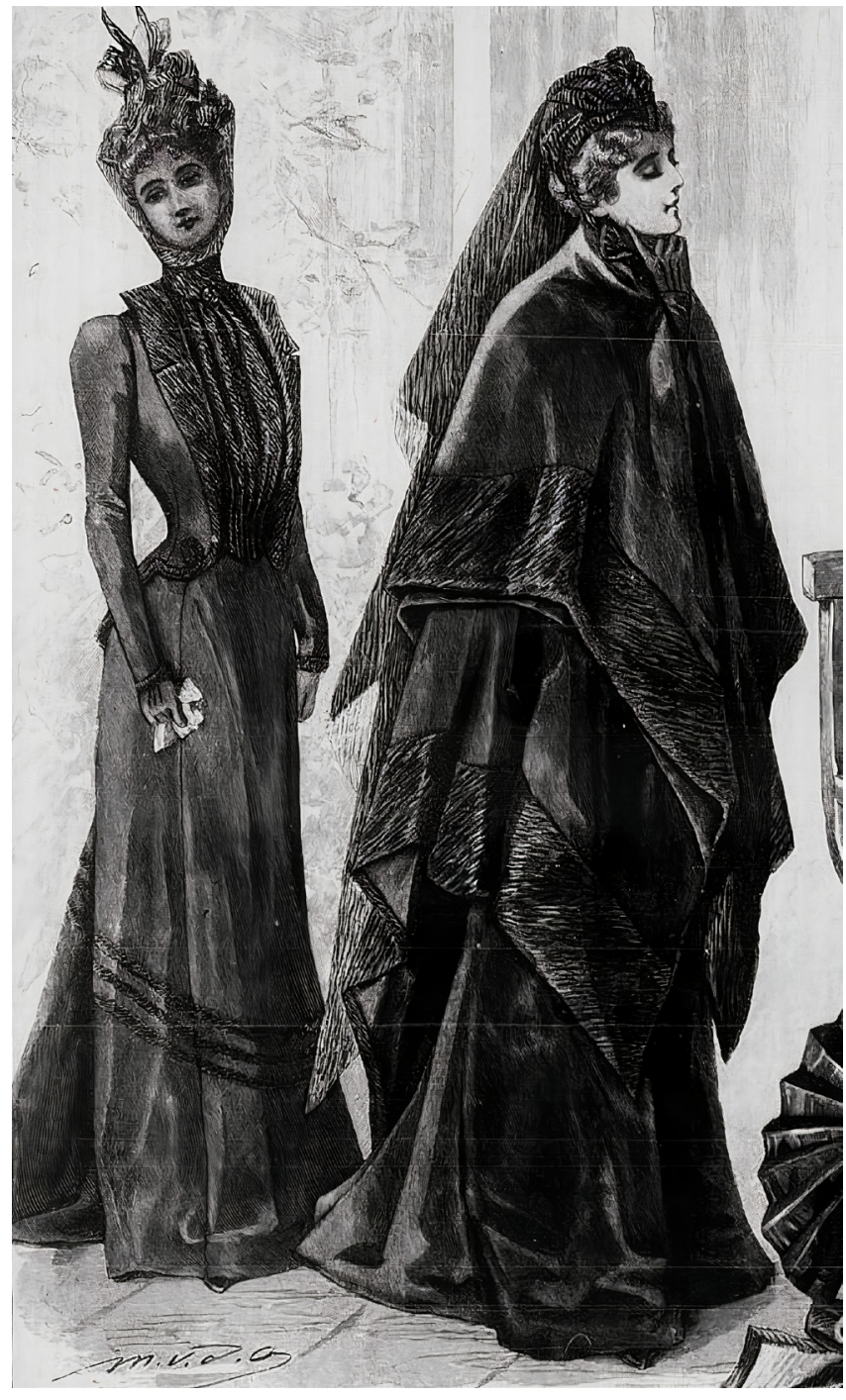

Figura 3 - Trajes femininos: à esquerda, compatível com o meio-luto (chapéu de abas curtas) e à direita, com o luto fechado (capota em ponta). Fonte: A Estação (1899, p. 144). 
99. A Fundação Instituto Feminino da Bahia, em Salvador, mantém uma significativa coleção de leques pretos do século XIX e começo do $\mathrm{XX}$, sendo alguns registrados como leques de luto.

100. Destacamos a coleção de joias de luto do Museu Histórico no Rio de Janeiro, que também tem ao menos nove itens em cabelos humanos - entre brincos, pulseiras e broches - feitos com a técnica conhecida como escumilha, em ótimo estado de conservação.

101. Por exemplo, o lenço com borda de plissadinho miúdo e bordado de bolinhas pretas, de ca. 1850-99, disponível em <https://bit. ly/3dLlJad $>$, e o lenço quadrado com borda preta e interior de bolinhas pretas, disponível em <https://bit. ly/3ke9c48>

102. Taylor (1983).

103. Ibid.

104. Candida (1892, p. 1). Manteve-se a grafia original.

105. "Lutos completos. Para viúva / Para qualquer senhora" (GAZETA DA TARDE, 1896, p. 3).

106. Sobre essas inconstâncias no luto inglês, Taylor afirma: "A dificuldade estava em estabelecer precisamente qual era o período correto de luto porque os conselhos diferiam de uma fonte para outra." (1983a, p. 134 , tradução nossa). No Brasil, o costume variava entre o que preconizava a Legislação Portuguesa, a moda francesa e o hábito vitoriano. Sobre esse tema em particular, há análises pormenorizadas em: SCHMITT, Juliana. Os tempos do luto em impressos brasileiros na segunda metade do século XIX. Revista Topoi. No prelo.
O leque, segundo a tabela de vestuários recomendados, apesar de adequado em qualquer luto, deveria ser apenas em tecido na viuvez (notadamente, durante a primeira metade da duração do luto), enquanto para as demais poderia ter hastes de madeira de ébano - um dos poucos materiais apropriados para este fim, ao lado da tartaruga e do azeviche. ${ }^{99}$ Esses poucos elementos discrepantes totalizavam uma diferença de 10 mil réis no preço final dos conjuntos. Os demais itens são semelhantes. As joias são restritas a pulseiras e broches de vidrilhos pretos - muito embora as viúvas só pudessem usá-las após o luto fechado. Concluímos, pelas fontes, que as joias deveriam ser muito simples, em aspecto e materiais. Quanto aos "brincos de aro de ouro", apesar não sabermos exatamente de qual modelo se trata, encontramos nos acervos dos museus pesquisados diversos brincos de luto em azeviche, em madeira e em cabelos humanos com aros de sustentação, fechos ou articulações em ouro. ${ }^{100}$

São mencionadas ainda as chamadas peças de "roupa branca" que, paradoxalmente, no luto, são "escurecidas", como os lenços e as meias. Nas listas, os lenços recomendados têm barrado em preto - detalhe pequeno, porém fundamental para adequá-los -, que poderia ser em forma de justaposição de tecidos, debrum ou delicados bordadinhos, conforme os exemplares pertencentes à coleção Costume Institute, do Metropolitan Museum de Nova York. ${ }^{101}$

As meias, que faziam parte do conjunto das roupas consideradas "de baixo", também sofriam alterações devido ao luto, devendo ser pretas. Segundo Taylor, mesmo as chemises, calçolas e anáguas, tradicionalmente brancas, eram guarnecidas com fitas pretas nestas ocasiões. ${ }^{102}$ Algumas mulheres incluíam camadas de anáguas na cor preta sobre as já usuais camadas na cor branca. ${ }^{103}$ Apesar da tabela não mencionar o material das meias, é de se supor que fossem em lã - nosso palpite é baseado na coluna "Correio da Moda", publicada n'A Estação de 15 de dezembro de 1892, que diz: "Os pormenores dos vestidos de luto tem por si mesmo grande importância. Por exemplo as luvas de fio d'escossia preta no verão e de lã no inverno são de rigor absoluto, assim como as meias e as saias pretas de lã, nunca de sêda." 104

Como se vê, a listagem sugerida pelo anúncio da Casa das Fazendas Pretas é curta, mas contempla uma variedade significativa de peças consideradas "itens básicos", poderíamos dizer, para o luto. Dez anos depois, uma nova tabela foi publicada. ${ }^{105}$ Nela, observamos algumas alterações, sendo as mais relevantes o "vestido de cauda", mais solene, para as viúvas, a inclusão de "1 par de luvas de seda" e o preço final do ensemble, aumentado em mais de 100\$000 em uma década. Esses apontamentos corroboram a percepção de que as regras do luto não eram objetivas, tampouco imutáveis. ${ }^{106}$ Elas oscilavam de acordo com a moda 
do momento, com a fonte das informações, com os materiais disponíveis no mercado e o contexto histórico específico.

As tabelas publicadas pela Casa das Fazendas Pretas têm parentesco direto com os livretos produzidos pelas maisons de devil francesas, citadas por Pierre Larousse no Grand dictionnaire universel du XIXe siècle, publicado em quinze volumes, entre 1866 e 1877. Segundo Larousse, as regras de luto eram então conhecidas em Paris e demais cidades da França por meio desses caderninhos, distribuídos ou vendidos a preços módicos pelas lojas especializadas em artigos de luto. ${ }^{107}$ Eles continham todas as informações necessárias ao enlutado do beau monde: os tempos de cada luto segundo o grau de parentesco com o morto e o que se poderia vestir em cada um deles, incluindo os materiais, as peças e os acessórios. ${ }^{108}$ É de se presumir que todos os produtos mencionados naquelas pequenas publicações de bolso fossem oferecidos pelas lojas que as encomendavam. Consideramos assim também as tabelas da Casa das Fazendas Pretas, que funcionavam como publicidade para a loja (que, por sua vez, forneceria todos os itens presentes nas listas), ao mesmo tempo que tentavam ensinar como se vestir para o luto.

\section{CONSIDERAÇÕES FINAIS}

A Casa das Fazendas Pretas se manteve na Avenida Central por mais de trinta anos, fechando definitivamente suas portas em 20 de fevereiro de 1938. 109 Após o falecimento dos irmãos Pedro e Octavio no mesmo ano de 1918, com um intervalo de apenas dois meses, ${ }^{110}$ Adelina - a mãe ou a filha, ou ambas - assume a administração dos negócios, com a ajuda de investidores. ${ }^{11}$ A morte de um deles - o empresário João Moreira de Araújo, em 13 de abril de $1937^{112}$ - parece ter sido definitiva para o fim da loja. Em 16 de novembro, inicia-se uma grande venda com o inédito desconto de 40\% válido para todo o estoque. ${ }^{13}$ Duas semanas depois, aparece o anúncio da liquidação total dos produtos, incluindo as vitrines, as bonecas expositoras, balcões e armações. ${ }^{114}$

Sua longa história de 67 anos confunde-se com as memórias de um Rio de Janeiro desenvolvimentista, em que os hábitos da antiga nobreza imperial conviviam com as dinâmicas da burguesia em ascensão. É significativa a história contada na primeira página do Diario Carioca de 18 de dezembro de 1955, sobre uma certa dona Adelaide Garcez Caldas Barreto, aniversariante do dia, que completara
107. Cf. Deuil (1866-1877).

108. Pudemos consultar um desses livretos, distribuído pela À L'Immortelle Maison Spéciale de Deuil, na Biblioteca Nacional da França. Trata-se de um caderninho produzido em 1872 , medindo $12 \times 10 \mathrm{~cm}$, com treze páginas e capa rosa, na qual se lê: Étiquette à suivre pour les deuils, o nome da loja e seu endereço.

109. Cf. Correio da Manhã, 2 dez. 1937, p. 6. O anúncio se repete nas edições de 5 , 9, 11 e 12 de dezembro e 9 e 30 de janeiro de 1938 .

110. Foi possível identificar registros precisos apenas da morte de Pedro, ocorrida em 23 de agosto, cujo enterro ocorreu no cemitério São João Batista, no Rio de Janeiro (A NOITE, 1924, p. 2; O JORNAL, 1921, p. 2). O Correio da Manhã de 18 de agosto de 1921 informa sobre o intervalo de apenas dois meses entre as mortes dos dois irmãos (p. 4).

111. "A. Queiroz \& Cia Limitada" aparece como proprietário da Casa das Fazendas Pretas no Almanak Laemmert de 1931 (p. 971, $1106,1713,1781,1865)$. No mesmo ano, o Correio da Manhã, em 18 de agosto de 1931, na página 5, parabeniza "Os srs A. Queiroz \& Comp. Limitada" pelo aniversário da loja. O artista plástico Adolpho Menge, marido de Adelina filha desde 1902, também teria entrado nos negócios após a morte dos cunhados.

112. Cf. Correio da Manhã, 14 abr. 1937 , p. 7.

113. O anúncio foi feito no Correio da Manhã de 14, $16,17,18,19,23$ e 25 de novembro de 1937 .

114. Cf. Correio da Manhã, 2 dez. 1937. O anúncio se repete nas edições de 5,9 , 
11 e 12 de dezembro e de 9 e 30 de janeiro de 1938 .

115. Diario Carioca, $18 \mathrm{dez}$. 1955, p. 1.

116. Contada, entre tantas publicações, na revista Sombra, edição de agosto de 1943, p. 73; na coluna de Macedo para o Correio da Manhã (1967, p. 15) e por Fontes (1927, p. 218).

117. Andrade (1960, p. 6).

118. Prado e Braga (2011, p. 36). cem anos. Segundo a matéria, a centenária, filha e viúva de desembargadores, "passa seu tempo sentada em uma cadeira de balanço, ouvindo rádio ou narrando a seus parentes histórias da monarquia que a viu nascer e que, ao se extinguir, deixou-the as raízes de uma saudade que nunca se apagou". Perguntada sobre os preparativos para a comemoração da data, respondeu: "Quero que o meu vestido para a missa seja comprado na Casa das Fazendas Pretas", 115 sem se atinar que a loja, àquela altura, não existia mais.

○ estabelecimento faz parte de um imaginário no qual se combinam o respeito pelos mortos, as normas de sociabilidade urbana e o status de ser cliente dos grandes magazines do centro da capital. São muitas as anedotas envolvendo seu nome, talvez a mais famosa seja a dos versinhos compostos por Olavo Bilac em busca de alguns trocados com publicidade: "Abram-se as bolsas, / abram-se as gavetas: / Liquida a Casa das Fazendas Pretas!". 116 Carlos Drummond de Andrade, em texto intitulado "Luto", publicado no jornal paulista A Tribuna, de 17 de janeiro de 1960, relembra a mais famosa loja de artigos pretos do Rio de Janeiro, clamando nostálgico: "os saudosistas recordarão". 117 Em entrevista à historiadora Silvana Gontijo, Antonieta Nava, viúva do escritor Pedro Nava, que em sua infância, na década de 1910, residia no Rio de Janeiro, conta:

[...] quando mamãe morreu, fiquei dois anos usando só roupas pretas. Meu pai mandou vir da Casa das Fazendas Pretas o meu luto e o de minha irmã. O traje era inteirinho preto: sapatos, meias, saias, blusa, chapéu com véu, luvas e bolsa. Não se podia usar joias; só as de ônix, mesmo assim se fossem muito discretas. ${ }^{118}$

Esses relatos, dentre muitos, são reveladores do papel de destaque que teve a Casa das Fazendas Pretas não apenas no contexto geral do comércio carioca entre a segunda metade do século XIX e a primeira do século XX, quando integrou a paisagem urbana representativa da modernização do Rio de Janeiro, mas, mais especificamente, de um tempo em que o luto se manifestava em seu ápice de rigor e detalhamento. $\bigcirc$ estabelecimento aberto por Pedro de Siqueira Queiroz e administrado, depois de sua morte, por seus filhos, se tornou sinônimo do zelo pelas regras do luto: o local por excelência para se encontrar os produtos adequados para seguilas com elegância e precisão. 


\section{REFERÊNCIAS}

FONTES IMPRESSAS

A NOITE. Rio de Janeiro: [s. n.], ano 14, n. 4.642, 27 out. 1924. "Sob o pallido esvoaçar da saudade". Disponível em: <https://bit.ly/3En0Dfq>. Acesso em: 10 set. 2021.

A NOTICIA. Rio de Janeiro: [s. n.], ano 2, n. 291, 1819 nov. 1895. "Sport". Disponível em: <https://bit.ly/3Enav94>. Acesso em: 11 set. 2021.

A NOTICIA. Rio de Janeiro: [s. $n$.], ano 7, n. 180, 34 ago. 1900. Disponível em: <https://bit. ly/3kedJna>. Acesso em: 11 set. 2021.

A TRIBUNA. Rio de Janeiro: [s. n.], ano 1, n. 64, 2 set. 1890. "Banco da Bolsa". Disponível em: <https://bit.ly/39eV44i>. Acesso em: 11 set. 2021.

ALMANAK ADMINISTRATIVO, MERCANTIL E INDUSTRIAL DO RIO DE JANEIRO. 17. ed. Rio de Janeiro: [s. n.], 1860. [Anúncio de] A Notre Dame de Paris. Disponível em: <https://bit. ly/3nDodhY $>$. Acesso em: 10 set. 2021.

ALMANAK ADMINISTRATIVO, MERCANTIL E INDUSTRIAL DO RIO DE JANEIRO. 32. ed. Rio de Janeiro: [s. $n$.], 1875. [Anúncio] “Especialidade de Fazendas Pretas para Luto". Disponível em: <https://bit.ly/2XpN1O5>. Acesso em: 10 set. 2021.

ALMANAK ADMINISTRATIVO, MERCANTIL E INDUSTRIAL DO RIO DE JANEIRO. 33. ed. Rio de Janeiro: [s. n.], 1876. [Anúncio de] Ao Paletó Fluminense. Disponível em: <https://bit. ly/3ErVtPd>. Acesso em: 10 set. 2021.

ALMANAK ADMINISTRATIVO, MERCANTIL E INDUSTRIAL DO RIO DE JANEIRO. 34. ed. Rio de Janeiro: [s. n.], 1877. [Anúncio de] Mme. Creten. Disponível em: <https://bit.ly/3kfyoaw $>$. Acesso em: 10 set. 2021.

ALMANAK ADMINISTRATIVO, MERCANTIL E INDUSTRIAL DO RIO DE JANEIRO. 39. ed. Rio de Janeiro: [s. $n$.], 1882. [Anúncio do] Bazar Elegante de Goulart \& Irmão. Disponível em: $<$ https://bit.ly/3lxG8nO>. Acesso em: 10 set. 2021.

ALMANAK ADMINISTRATIVO, MERCANTIL E INDUSTRIAL DO RIO DE JANEIRO. 40. ed. Rio de Janeiro: [s. n.], 1883. "Associação dos Empregados no Commercio do Rio de Janeiro". Disponível em: <https://bit.ly/3ziuXEn>. Acesso em: 10 set. 2021.

ALMANAK ADMINISTRATIVO, MERCANTIL E INDUSTRIAL DO RIO DE JANEIRO. 42. ed. Rio de Janeiro: [s. n.], 1885. [Anúncio da] Tinturaria do Commercio. Disponível em: <https://bit. ly/3nGFtmC>. Acesso em: 10 set. 2021. 
ALMANAK LAEMMERT: ADMINISTRATIVO, MERCANTIL E INDUSTRIAL DO RIO DE JANEIRO. 87. ed. Rio de Janeiro: [s. n.], 1931. Disponível em: <https://bit.ly/2Xv3u5r >. Acesso em: 10 set. 2021.

ANDRADE, Carlos Drummond de. Luto. A Tribuna, Santos, ano 66, n. 253, p. 6, 17 jan. 1960. Disponível em: <https://bit.ly/3kgpwl5>. Acesso em: 11 set. 2021.

ARAUJO, Ignez Barreto Correia de. Dois Archivos Nacionaes. O Observador Econômico $e$ Financeiro, Rio de Janeiro, ano 2, n. 23, p. 3844, 1937. Disponível em: <https://bit.ly/39axXI3>. Acesso em: 11 set. 2021.

CANDIDA, Paula. Correio da Moda. A Estação: Jornal Illustrado para a Família, Rio de Janeiro, ano 21, n. 23, p. 1, 15 dez. 1892. Disponível em: <https://bit.ly/3ltaTu8>. Acesso em: 11 set. 2021.

CIDADE DO RIO. Rio de Janeiro: [s. n.], ano 12, n. 183, 3 ago. 1900. "Echos fúnebres". Disponível em: <https://bit.ly/39jt7s1>. Acesso em: 11 set. 2021.

COLEÇÃO JUNTA COMERCIAL, código 46, livro 645, registro 10.868, 1871.

COLEÇÃO JUNTA COMERCIAL, livro 38, registro 9.563, 1901.

COLEÇÃO JUNTA COMERCIAL, livro 43, registro 15.285, 1875.

CORREIO DA MANHÃ. Rio de Janeiro: $[s . n$.], ano 21, n. 8.203, 18 ago. 1921. "Publicações especiaes: O quinquagésimo anniversario da Casa das Fazendas Pretas". Disponível em: <https://bit.ly/3Er7yV5>. Acesso em: 10 set. 2021.

CORREIO DA MANHÃ. Rio de Janeiro: [s. n.], ano 31, n. 11.249, 18 ago. 1931. "Casa das Fazendas Pretas". Disponível em: <https://bit.ly/3zh9ICE>. Acesso em: 10 set. 2021.

CORREIO DA MANHÃ. Rio de Janeiro: [s. n.], ano 36, n. 13.013, 14 abr. 1937. "Syndicato dos Lojistas do Rio de Janeiro”. Disponível em: <https://bit.ly/3nGpyVd>. Acesso em: 11 set. 2021.

CORREIO DA MANHÃ. Rio de Janeiro: [s. $n$.], ano 37, n. 13.210, 2 dez. 1937. [Anúncio] "A Casa das Fazendas Pretas". Disponível em: <https://bit.ly/2VKt31o>. Acesso em: 11 set. 2021.

CORREIO DO BRAZIL. Rio de Janeiro: [s. n.], ano 1, n. 17, 18 jan. 1872. "Especiaes". Disponível em: <https://bit.ly/2Xt1jz6>. Acesso em: 11 set. 2021.

DIARIO CARIOCA. Rio de Janeiro: [s. $n$.], ano 28, n. 8.415, 18 dez. 1955. "Faz cem anos hoje com saudade da côrte de Pedro II". Disponível em: <https://bit.ly/3hEzGtS>. Acesso em: 11 set. 2021.

DIARIO DE NOTICIAS. Rio de Janeiro: [s. n.], ano 1, n. 75, 20 ago. 1885. Disponível em: <https://bit.ly/3keaV9J>. Acesso em: 10 set. 2021. 
DIARIO DE NOTICIAS. Rio de Janeiro: [s. n.], ano 10, n. 2.966, 30 ago. 1893. "Sport". Disponível em: <https://bit.ly/39cOPOz>. Acesso em: 10 set. 2021.

DIARIO DO COMMERCIO. Rio de Janeiro: $[s . n$.], ano 1, n. 21, 24 dez. 1888. "Exposição Nacional”. Disponível em: <https://bit.ly/3EpZEuX>. Acesso em: 11 set. 2021.

FONTES, Martins. O colar partido. Santos: B. Barros e Cia, 1927.

GAZETA DA TARDE. Rio de Janeiro: [s. n.], 15 set. 1896. "Lutos completos. Para viúva / Para qualquer senhora".

GAZETA DA TARDE. Rio de Janeiro: [s. $n$.], ano 8, n. 45, $1^{\circ}$ mar. 1887. Disponível em: <https:// bit.ly/2XB8yFg>. Acesso em: 13 set. 2021.

GAZETA DA TARDE. Rio de Janeiro: [s. $n$.], ano 16, n. 265, 26 set. 1895. Disponível em: <https:// bit.ly/3tNzRYJ>. Acesso em: 14 set. 2021.

GAZETA DE NOTICIAS. Rio de Janeiro: [s. n.], 22 set. 1884.

GAZETA DE NOTICIAS. Rio de Janeiro: [s. n.], ano 2, n. 17, 18 jan. 1877. Disponível em: $<$ https://bit.ly/39dxiFY>. Acesso em: 14 set. 2021.

GAZETA DE NOTICIAS. Rio de Janeiro: [s. n.], ano 9, 2 jul. 1883. "Gazetilha". Disponível em: <https://bit.ly/3zjOaW9>. Acesso em: 14 set. 2021.

GAZETA DE NOTICIAS. Rio de Janeiro: [s. n.], ano 22, n. 84, 24 mar. 1896. "Questões do dia". Disponível em: <https://bit.ly/3tL5v9j>. Acesso em: 14 set. 2021.

GAZETA DE NOTICIAS. Rio de Janeiro: [s. n.], ano 25, n. 249, 6 set. 1899. "Associação dos Empregados no Commercio do Rio de Janeiro". Disponível em: <https://bit.ly/3EsQGNM>. Acesso em: 14 set. 2021.

GAZETA DE NOTICIAS. Rio de Janeiro: [s. n.], ano 32, n. 105, 15 abr. 1906. "Fazendas Pretas". Disponível em: <https://bit.ly/3nG6RkQ>. Acesso em: 14 set. 2021.

JORNAL DO BRASIL. Rio de Janeiro: [s. $n$.], ano 6, n. 185, 3 jul. 1896. Disponível em: <https:// bit.ly/3hDYBhp>. Acesso em: 14 set. 2021.

JORNAL DO COMMERCIO. Rio de Janeiro: [s. $n$.], 3 nov. 1888.

JORNAL DO COMMERCIO. Rio de Janeiro: [s. $n$.], 18 ago. 1871. "Avisos". Disponível em: $<$ https://bit.ly/3ChPjzf>. Acesso em: 14 set. 2021. 
JORNAL DO COMMERCIO. Rio de Janeiro: [s. n.], ano 56, n. 186, 6 jul. 1877. [Anúncio da] Casa das Fazendas Pretas. Disponível em: <https://bit.ly/3kgEGH5>. Acesso em: 15 set. 2021.

JORNAL DO COMMERCIO. Rio de Janeiro: [s. n.], ano 65, n. 238, 26 ago. 1887. Disponível em: <https://bit.ly/3ltrr57>. Acesso em: 14 set. 2021.

JORNAL DO COMMERCIO. Rio de Janeiro: [s. n.], ano 67, n. 57, 27 fev. 1889. [Anúncio da] Bière Saint-Germain. Disponível em: <https://bit.ly/3CdXNrc>. Acesso em: 14 set. 2021.

JORNAL DO COMMERCIO. Rio de Janeiro: [s. n.], ano 68, n. 243, 12 fev. 1890. [Anúncio] "Lutos Completos”. Disponível em: <https://bit.ly/3tJ0YUU>. Acesso em: 14 set. 2021.

JORNAL DO COMMERCIO. Rio de Janeiro: [s. n.], ano 68, n. 245, 3 set. 1890. [Anúncio da] Casa das Fazendas Pretas. Disponível em: <https://bit.ly/3nzVYRs>. Acesso em: 15 set. 2021.

JORNAL DO COMMERCIO. Rio de Janeiro: [s. n.], ano 69, n. 272, $1^{\circ}$ out. 1891. [Anúncio da] Casa das Fazendas Pretas. Disponível em: <https://bit.ly/3tNTyjd>. Acesso em: 14 set. 2021.

JORNAL DO COMMERCIO. Rio de Janeiro: [s. n.], ano 75, n. 87, 98, 67 abr. 1896. "Folhetim do Jornal do Commercio”. Disponível em: <https://bit.ly/3hAZ4kg>. Acesso em: 14 set. 2021.

MACEDO, Sérgio D. T. Historinhas. Correio da Manhã, Rio de Janeiro, p. 15, 31 dez. 1967. Disponível em: <https://bit.ly/3AugKFu>. Acesso em: 11 set. 2021.

NOVIDADES. Rio de Janeiro: [s. n.], ano 1, n. 63, 28 mar. 1887. "Lutos Completos". Disponível em: <https://bit.ly/3Ak41VR>. Acesso em: 15 set. 2021.

NOVIDADES. Rio de Janeiro: [s. n.], ano 4, n. 185, 28 ago. 1890. [Anúncio do] Banco da Bolsa. Disponível em: <https://bit.ly/3Eor9F8>. Acesso em: 15 set. 2021.

O APOSTOLO: PERIODICO RELIGIOSO, MORAL E DOUTRINÁRIO, CONSAGRADO AOS INTERESSES DA RELIGIÃO E DA SOCIEDADE. Rio de Janeiro: [s. $n$.], ano 12, n. 6, 17 jan. 1877. "Expediente do bispado". Disponível em: <https://bit.ly/3Erns1u>. Acesso em: 11 set. 2021.

O CRUZEIRO. Rio de Janeiro: [s. n.], ano 1, n. 86, 27 ago. 1890. [Anúncio do] Banco da Bolsa. Disponível em: <https://bit.ly/3Aukgja>. Acesso em: 15 set. 2021.

O JORNAL. Rio de Janeiro: [s. n.], ano 3, n. 788, 18 ago. 1921. "O quinquagésimo anniversario da Casa das Fazendas Pretas”. Disponível em: <https://bit.ly/3ziOUuL>. Acesso em: 15 set. 2021.

O PAIZ. Rio de Janeiro: [s. n.], ano 3, n. 108, 19 abr. 1886. "Noticiario". Disponível em: <https:// bit.ly/3zsgplL>. Acesso em: 14 set. 2021. 
O PAIZ. Rio de Janeiro: [s. n.], ano 22, n. 7.989, 18 ago. 1906. "A Casa das Fazendas Pretas. 35 annos". Disponível em: <https://bit.ly/3CmxfE7>. Acesso em: 15 set. 2021.

SOMBRA. Rio de Janeiro: [s. n.], ano 3, n. 20, ago. 1943. "Olavo Bilac". Disponível em: <https:// bit.ly/3hEMiBm>. Acesso em: 11 set. 2021.

LIVROS, ARTIGOS E TESES

BONADIO, Maria Claudia. Moda e sociabilidade: mulheres e consumo na São Paulo dos anos 1920. São Paulo: São Paulo, 2007.

BOUCHER, François. História do vestuário no Ocidente. São Paulo: Cosac Naify, 2010.

CUMMING, Valerie; CUNNINGTON, Cecil Willett; CUNNINGTON, Phillis Emily. The dictionary of fashion history. Oxford: Berg, 2010.

DEUIL. In: LAROUSSE, Pierre. Grand dictionnaire universel du XIXe siècle: français, historique, géographique, mythologique, bibliographique.... Paris: [s. n.], 1866-1877. p. 632634.

ÉTALAGE. In: LAROUSSE Dictionnaire de Français. Paris: [s. n.], c2021. Disponível em: <https:// bit.ly/3B1sorE>. Acesso em: 8 set. 2021.

FERREZ, Marc. Avenida Central. 8 de março de 1903 - 15 de novembro de 1906. Rio de Janeiro: [s. n.], 1907. Disponível em: <https://bit.ly/3dPC79y>. Acesso em: 8 set. 2021.

GORBERG, Marissa. Parc Royal: um magazine na modernidade carioca. 2013. Dissertação (Mestrado em História, Política e Bens Culturais) - Fundação Getúlio Vargas, Rio de Janeiro, 2013.

HOWARTH, Glennys; LEAMAN, Oliver. Enciclopédia da morte e da arte de morrer. Rio de Mouros: Printer Portuguesa, 2004.

ITALIANO, Isabel et al. Para vestir a cena contemporânea: moldes e moda no Brasil do século XIX. São Paulo: Estação das Letras e Cores, 2015.

LOS ANGELES COUNTY MUSEUM OF ART. Woman's Bonnet. United States: [s. $n$.], [18?]. Disponível em: <https://bit.ly/2yuEP47>. Acesso em: 8 set. 2021.

NEEDELL, Jeffrey. A tropical Belle Époque: culture and society in turn-of-the-century Rio de Janeiro. Cambridge: Cambridge University Press, 1987.

PRADO, Luís André do; BRAGA, João. História da moda no Brasil: das influências às autorreferências. São Paulo: Disal, 2011. 
RAINHO, Maria do Carmo Teixeira. A cidade e a moda: novas pretensões, novas distinções: Rio de Janeiro, século XIX. Brasília, DF: Editora UnB, 2002.

SCHMITT, Juliana. Mortes vitorianas: corpos, luto e vestuário. São Paulo: Alameda, 2010.

SENNETT, Richard. O declínio do bomem público: as tiranias da intimidade. São Paulo: Companhia das Letras, 1988.

TAYLOR, Lou. Mourning Dress: a costume and social history. London: George Allen and Unwin, 1983a.

TAYLOR, Lou. The mourning dress and textile industries. In: Mourning dress: a costume and social history. London: George Allen and Unwin, 1983b. p. 188-223.

ZOLA, Émile. O paraíso das damas. São Paulo: Estação Liberdade, 2008.

Artigo apresentado em: 06/01/2021. Aprovado em: 19/03/2021. 